\title{
A Whole-System Approach to Understanding Agricultural Chemicals in the Environment
}

The effects of the use of agricultural chemicals and other practices associated with agriculture on the quality of streams and groundwater is well known; however, less is known about how those effects may vary across different geographic regions of the Nation. Scientists at the U.S. Geological Survey (USGS) are conducting studies on the transport and fate of agricultural chemicals in diverse agricultural settings across the country using comparable and consistent methodology and study designs (fig. 1; Capel and others, 2004; Capel and others, 2008). Assessments in five study areas have been completed, and the results highlight how environmental processes and agricultural practices interact to affect the movement and transformation of agricultural chemicals in the environment. The studies address major environmental compartments, including surface water, groundwater, the unsaturated zone, the streambed, and the atmosphere, as well as the pathways that interconnect these compartments. The study areas represent major agricultural settings, such as irrigated diverse cropping in the West and corn and soybean row cropping in the Midwest and, therefore, findings are relevant throughout much of the Nation.

\section{Major Findings}

Findings from these studies show how environmental processes and agricultural practices act together to determine the transport and fate of agricultural chemicals in the environment. Selected highlights from USGS studies featured in the Journal of Environmental Quality are presented here:

\section{USGS Studies Featured in Journal of Environmental Quality}

Results from five studies on the transport and fate of agricultural chemicals were published as a "Special Submissions" section in the May-June 2008 volume of the Journal of Environmental Quality (volume 37, issue 3). Study findings highlighted in this fact sheet are available in more detail in selected papers from that volume: Bayless and others (2008), Capel and others (2008), Domagalski and others (2008), Essaid and others (2008), Fisher and Healy (2008), Green and others (2008a, 2008b), Hancock and others (2008), Puckett and others (2008), Steele and others (2008), Vogel and others (2008), and Webb and others (2008).
- Hydrologic and landscape modifications — such as irrigation and enhanced soil drainage through tile drains and drainage ditcheschange the magnitude and timing of water flow and agricultural chemical transport into and through the hydrologic system.

- Agricultural chemicals, including nitrogen compounds, pesticides, and pesticide breakdown products, commonly are present in precipitation, surface water, unsaturated-zone soil water, and groundwater in agricultural areas.

- Differences in the rates of agricultural chemical movement from land surface to groundwater and streams are controlled by many factors, including the characteristics of the chemical (such as solubility, sorption characteristics, and susceptibility to biochemical transformation), the timing of chemical application relative to irrigation and precipitation, the volume of water inputs relative to evapotranspiration rates, and the flow paths that water follows from fields to groundwater and streams.

- Nitrate is the predominant form of nitrogen present in ground and surface waters of the agricultural watersheds studied.

- Attenuation of nitrate in groundwater and the streambed occurs to some degree in all watersheds. However, this attenuation is limited where (1) flow rates are fast relative to biochemical reaction rates, (2) the volume of water moving through reactive zones is small, or (3) the supply of organic substrates is not adequate to support biological processes.

- Instream processes such as photosynthesis and respiration can change nitrate loads in surface water.

- Differences in the concentrations and loads of nitrogen among streams reflect differences in the hydrologic characteristics of these watersheds.

- The load of nitrogen leaving the watersheds was closely correlated with the amount of water flowing out of the watershed: Stream exports of nitrogen were greatest where surface-water outflows were greatest.

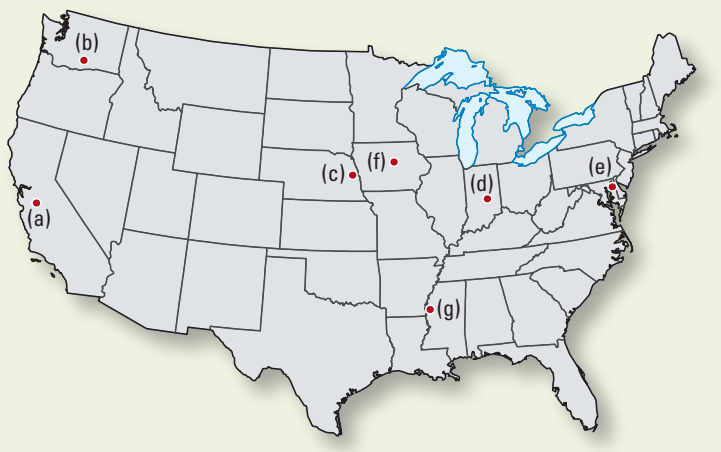

Figure 1. Research was conducted in five study areas: (a) Lower Merced River basin, California; (b) Granger Drain basin, Washington; (c) Maple Creek basin, Nebraska; (d) Sugar Creek basin, Indiana; and (e) Morgan Creek basin, Maryland. Similar studies are underway in two additional study units: (f) South Fork lowa River basin, lowa, and (g) Bogue Phalia basin, Mississippi. 


\section{Characteristics of the Study Areas}

The studies were designed at nested scales with most work conducted within a focus watershed nested within a larger study basin (table 1). Each study basin was nested within a larger study unit where previous investigations have been conducted by the USGS National Water-Quality Assessment Program (Capel and others, 2004).

The California and Washington study areas (fig. 1) are characterized by semiarid to arid climates and, in both, more than 95 percent of crops are irrigated. The sources of irrigation water in these two areas, however, differ substantially. Most irrigation water in the California study area is pumped from deep groundwater, whereas in the Washington study area an extensive network of water delivery canals distribute surface water from the Yakima River. Agriculture comprises predominantly orchards, vineyards, row crops, dairies, and cattle feedlots in both study areas.

The study areas in Nebraska, Indiana, and Maryland (fig. 1) are characterized by humid climates, each receiving 30 to 40 inches of precipitation each year. These three study areas are dominated by corn and soybean row cropping, but several differences exist that can affect the movement of agricultural chemicals. Specifically, irrigation is used to augment water needs in the Nebraska study area, where 30 percent of the farmland is irrigated from deep wells. Subsurface drains, used to move excess water from the root zone, are widely used in the Indiana study area, where topography is flat and soils are relatively high in clay content. In contrast, soils in the Maryland study area are permeable and well drained, and precipitation and natural soil drainage are adequate for agricultural activities.

Table 1. Drainage areas for study basins and focus watersheds.

[Abbreviation: $\mathrm{km}^{2}$, square kilometer]

\begin{tabular}{llclc}
\hline \multicolumn{1}{c}{ State } & \multicolumn{1}{c}{$\begin{array}{c}\text { Study } \\
\text { basin }\end{array}$} & $\begin{array}{c}\text { Drainage } \\
\text { area } \\
\left(\mathbf{k m}^{2}\right)\end{array}$ & $\begin{array}{c}\text { Focus } \\
\text { watershed }\end{array}$ & $\begin{array}{c}\text { Drainage } \\
\text { area } \\
\left(\mathbf{k m}^{2}\right)\end{array}$ \\
\hline California & Lower Merced River & 831 & Mustang Creek & 18 \\
Washington & Granger Drain & 160 & DR2 Drain & 5.5 \\
Nebraska & Maple Creek & 955 & unnamed tributary & 1.5 \\
Indiana & Sugar Creek & 240 & Leary-Weber Ditch & 7.2 \\
Maryland & Morgan Creek & 31 & Morgan Creek & 31 \\
\hline
\end{tabular}

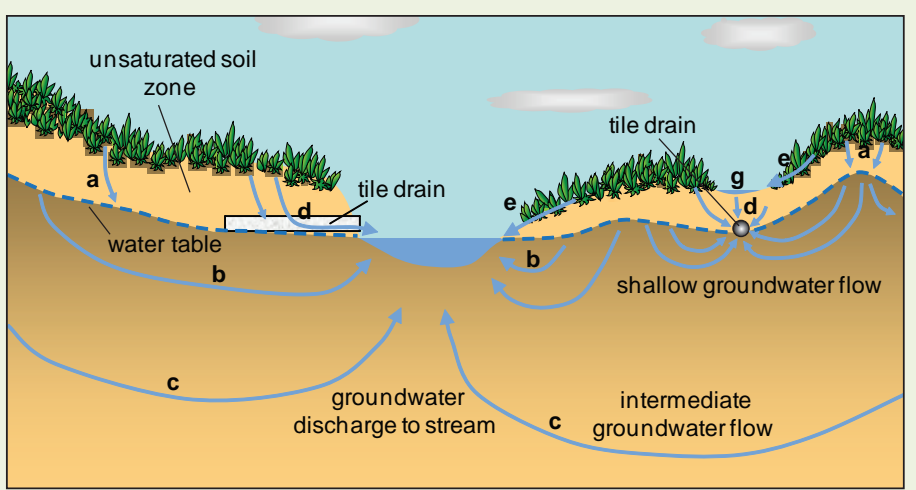

Figure 2. Various relatively short flow paths may connect agricultural fields to streams in areas where the water table is shallow: (a) infiltration to shallow groundwater, (b) shallow groundwater flow, (c) intermediate groundwater flow, (d) seepage to tile drains, and (e) overland flow, which may result in (g) temporary ponding.

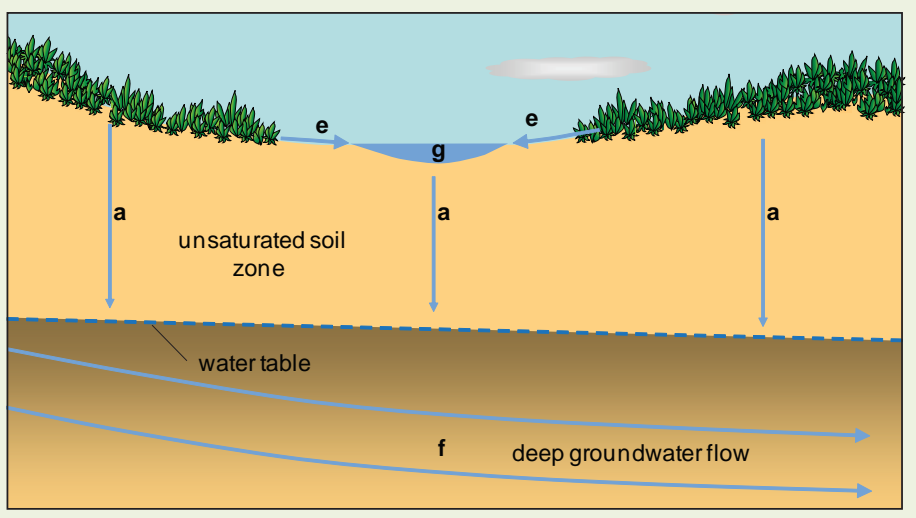

Figure 3. Many flow paths from agricultural fields may bypass local streams in areas where the water table is deep: (a) infiltration to deep ground water, (e) overland flow to ( $g$ ) temporary ponds, and (f) deep groundwater flow.

\section{How Agricultural Fields are Linked to Groundwater and Streams}

The right amount of water at the right time is critical to successful agriculture. When the water supply is too abundant, engineered drainage systems, such as the subsurface "tile" drains and ditches at the Indiana and Washington sites, are used. When the natural water supply is too scarce, such as at the California and Washington sites, water is added by engineered irrigation systems. These modifications to the natural hydrology affect not only the amount of water in a watershed at any given time, but also the timing and manner in which water moves through and out of the watershed to larger streams, lakes, estuaries, and, eventually, the ocean.

Typically, at least one-half of the water that reaches agricultural fields from precipitation and irrigation is released to the atmosphere through evapotranspiration (the combined processes of evaporation and plant transpiration). When precipitation or irrigation exceeds evapotranspiration, excess water can follow a variety of pathways (flow paths) from fields. The predominant pathways vary among environmental settings, depending on local conditions such as soil characteristics, land slope and topography, precipitation (or irrigation) patterns, depth below the land surface to the water table, and the presence of artificial drainage systems such as tiles (figs. 2 and 3 ).

Where the water table is shallow (fig. 2) and no artificial drainage system is present, excess water at the land surface moves downward through the unsaturated soil zone and enters the groundwater system (fig. 2a). If a nearby stream intersects the water table, groundwater discharges into the stream via short, shallow flow paths (fig. 2b). If the stream is more distant, groundwater follows somewhat longer, deeper flow paths to the stream (fig. 2c). Where artificial drains are present, water is intercepted by the drainage system and carried quickly to the stream (fig. 2d). If downward water movement (infiltration) into the subsurface is hindered by low permeability soil or when the infiltration capacity of the soil is exceeded due to an intense rainfall or irrigation event, water flows across the land surface as overland flow (fig. 2e) and may accumulate to form temporary ponds or streams in topographic lows (fig. 2g).

At locations where the water table is deep (fig. 3), flow paths through the unsaturated soil zone to groundwater are longer (fig. 3a) and groundwater follows deeper, longer flow paths to more distant streams or lakes (fig. 3f). When precipitation or irrigation exceed the infiltration capacity of the soil, water may accumulate to form temporary ponds or streams in topographic lows (fig. 3g).

As water moves along various flow paths from fields, dissolved and suspended materials, such as agricultural chemicals, are transported along its route. 


\section{Hydrology Is Key}

An accounting of local hydrology - the amount of water that enters the watershed, moves within the watershed, and leaves the watershed-formed the foundation for understanding the movement of agricultural chemicals in each of the focus watersheds. Stream hydrographs, which show the amount and timing of surface water flowing out of each of the focus watersheds, illustrate some of the large differences in hydrology among these five study areas (fig. 4).

Despite similarities in climate and cropping systems at the California and Washington sites (figs. 4A and 4B), differences in irrigation practices have resulted in large differences in streamflow at the catchment outflows. Long-term irrigation from groundwater has lowered the water table substantially in the Mustang Creek catchment, increasing the distance between the stream and the underlying groundwater system. Groundwater is pumped as needed and is applied to crops using mostly drip and sprinkler methods, which generate little runoff. As a result of the deep water table at Mustang Creek, (1) the time it takes for water to travel downward to groundwater is considerable, (2) there is no groundwater discharge to the creek, and (3) streamflow typically occurs only as a short-term response to winter or early spring precipitation (fig. 4A). In contrast, long-term irrigation with imported surface water at the Washington site has raised the local water table and created a perennial stream from year-round groundwater base flow (fig. 4B).

Hydrographs for the three catchments where irrigation is limited or not used at all (fig. 4C-E) show similar patterns of base flow, with intermittent spikes in discharge in response to precipitation or occasional irrigation. Similar to the California site, the water table underlying the Nebraska watershed is more than 70 meters below land surface and therefore too deep to provide flow to the stream. Streamflow occurs only as a result of overland flow or shallow soil drainage from precipitation or occasional irrigation events (fig. 4C). Overland flow and drainage from subsurface drains account for nearly all streamflow at the Indiana site (fig. 4D). During mid to late summer, streamflow in Leary-Weber Ditch generally ceases when precipitation no longer exceeds evapotranspiration requirements. At the Maryland site (fig. 4E), more than one-half of the streamflow comes from the discharge of shallow groundwater to the stream and the remainder comes from overland flow from precipitation, which generally occurs throughout the year. Together, these two sources provide substantial year-round flow in Morgan Creek.
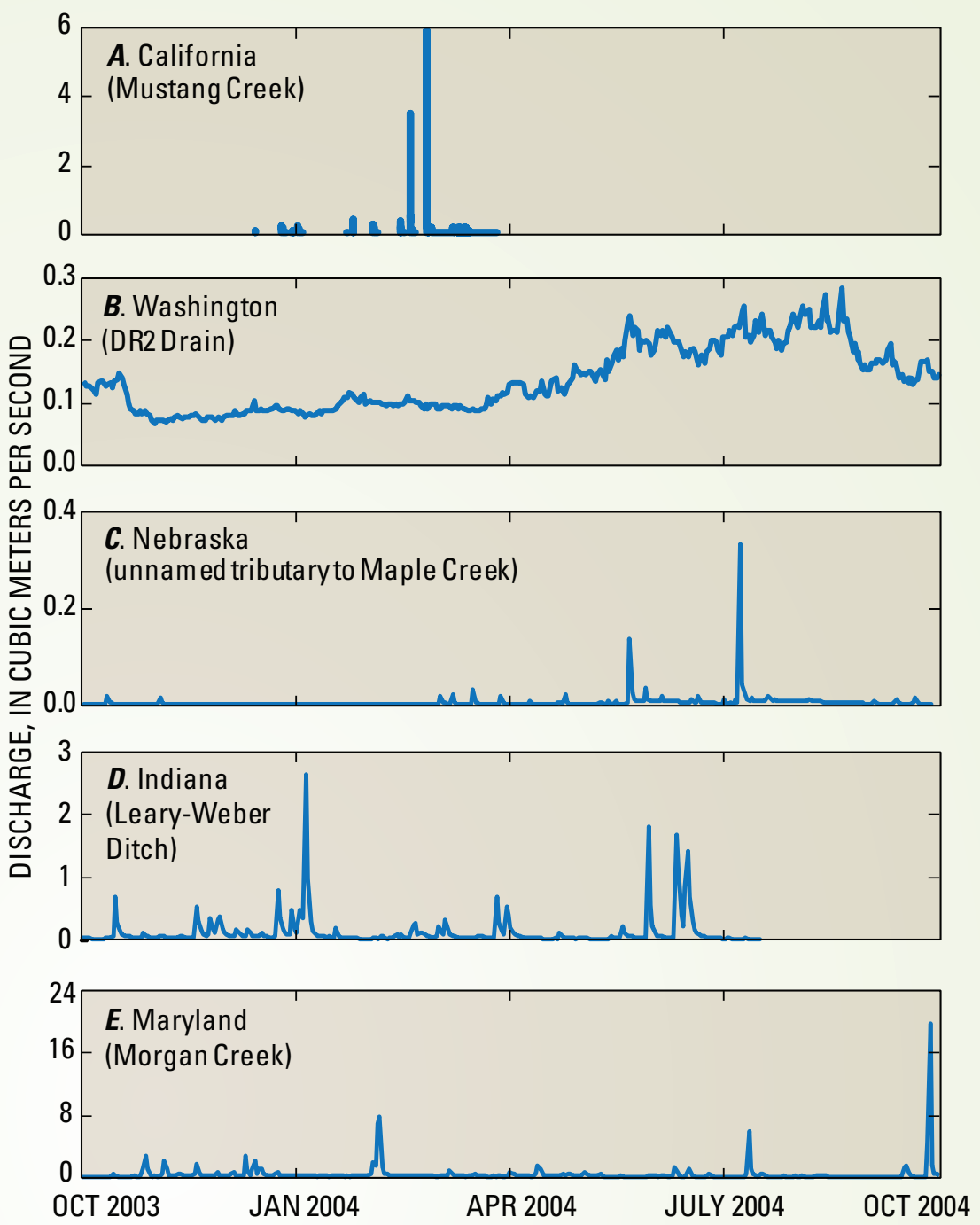

Figure 4. Hydrographs for the surface-water outflows of the five focus watersheds show large differences in the magnitudes and annual distribution of streamflow in these watersheds. [Note scale for stream discharge is different for each graph.]

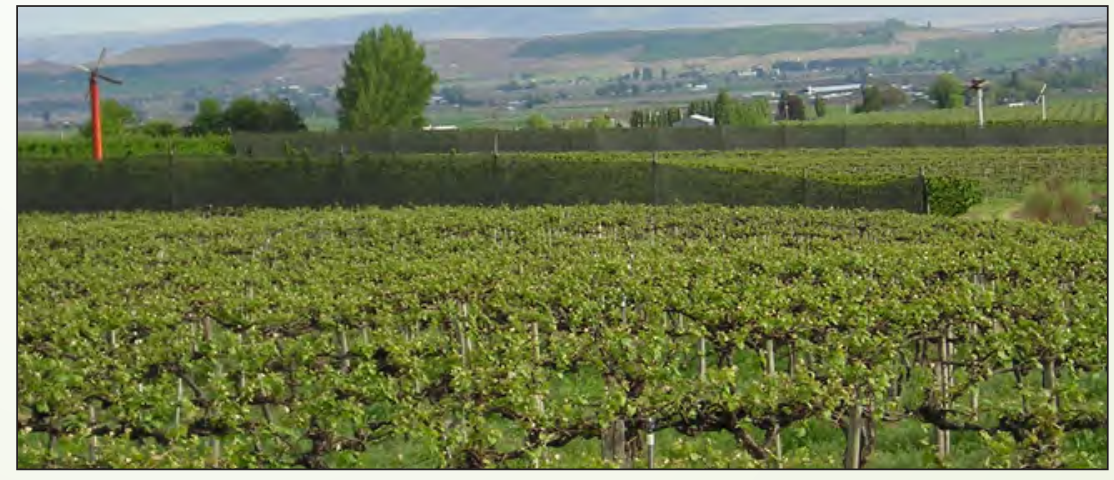

A vineyard grows on an irrigated hillside in the Granger basin, Washington.

\section{Excess Fertilizer in the Environment}

Nitrogen is a critical nutrient for crop growth, and large amounts—-from both commercial fertilizer and livestock manures—are applied to agricultural lands to increase crop quality and productivity. However, when more nitrogen is supplied than crops can utilize, surplus nitrogen - often in the form of nitrate-is transported to groundwater and streams. Excessive nitrate in drinking water poses a risk to human health and in streams can stimulate excessive growth of algae and other aquatic plants. Besides the nuisance these plants can pose, decay of the increased organic matter consumes available oxygen in the water and leads to low-oxygen conditions that threaten aquatic life. The harmful effects of nutrient enrichment can be carried downstream and are now known to be affecting a considerable portion of the Nation's fresh-water resources (Dodds and others, 2009) and coastal zones, particularly in the Gulf of Mexico (U.S. Environmental Protection Agency, 2008). 


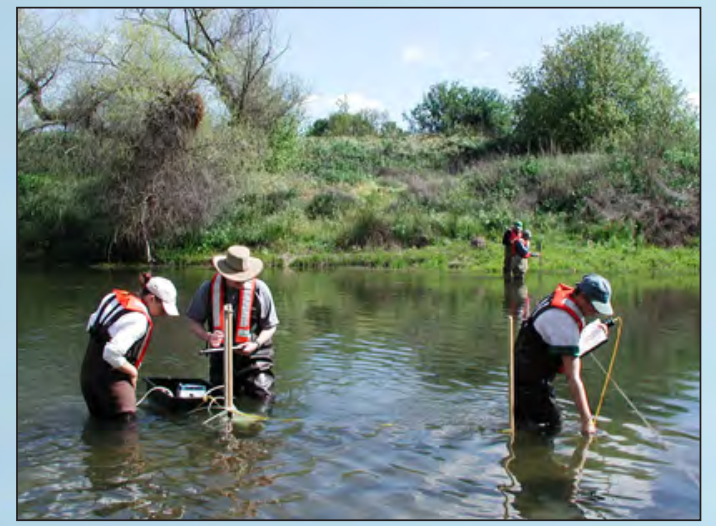

USGS scientists collect hydrologic data in the

Lower Merced River basin, California.

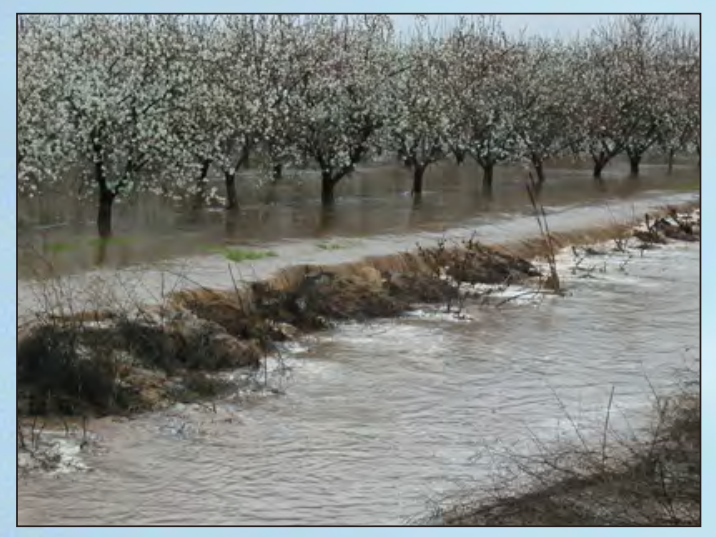

Excess water produces overland flow in an almond orchard in the Lower Merced River basin, California.
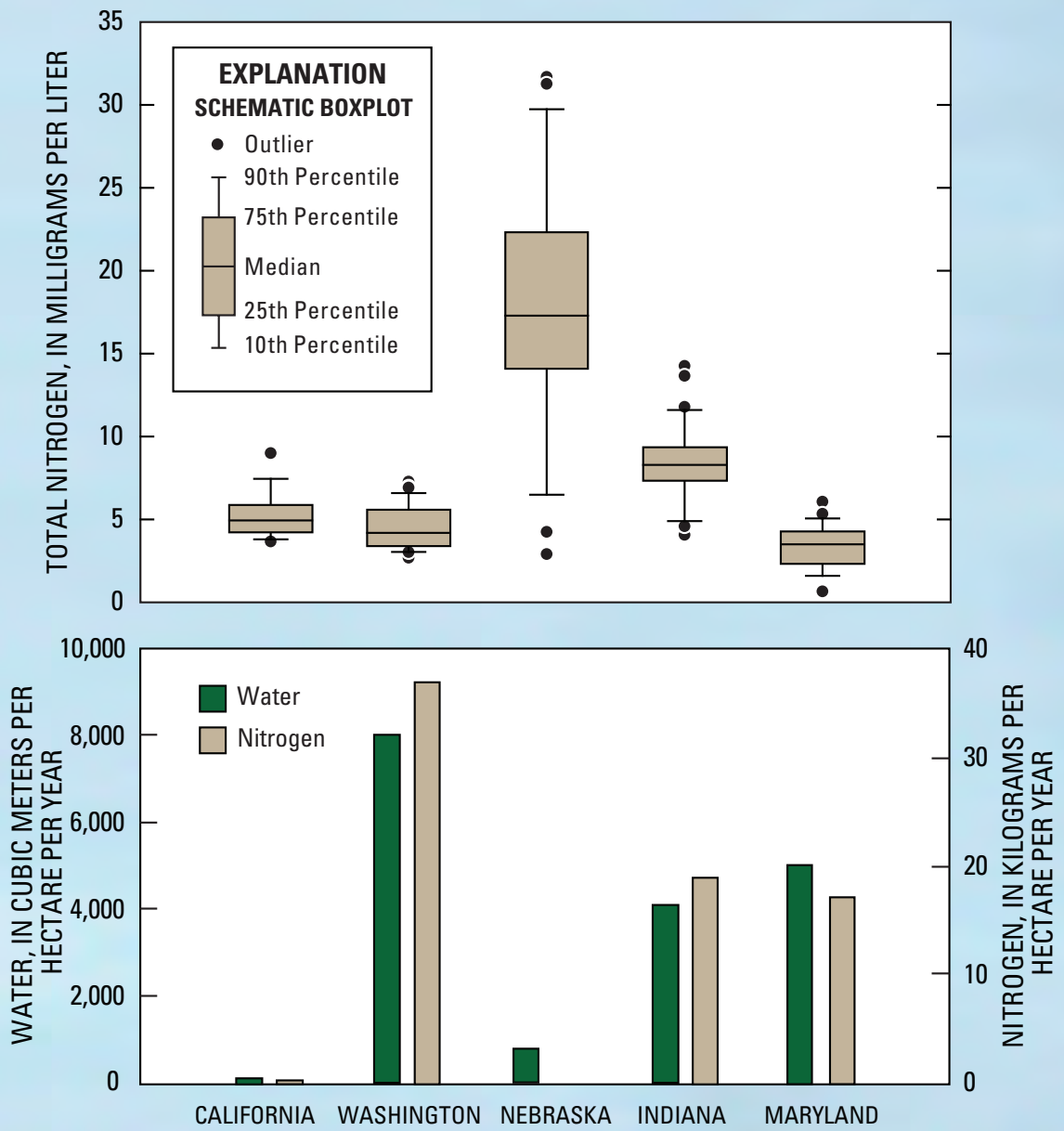

Figure 5. Concentrations of total nitrogen measured at the focus watershed outflows during 2004 show differences in both the magnitudes of peak concentrations and the range of concentrations. Annual yields of water (annual watershed outflow/watershed area) and nitrogen (annual load exported in the stream/watershed area) from the focus watersheds were closely correlated and show that stream exports of nitrogen are greatest where surface-water outflows are greatest. [Insufficient data to calculate nitrogen yield for the Nebraska watershed.]

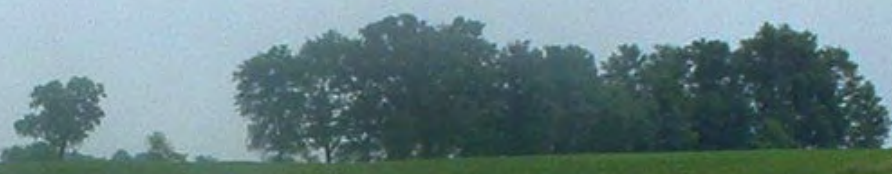




\section{Nitrogen Concentrations in Streams and Nitrogen Exports From Catchments Reflect Differences in Hydrology}

Comparison of the concentrations of total nitrogen measured in the streams of the focus watersheds illustrates the influence of hydrologic conditions on the transport of nitrogen from fields (fig. 5). In addition to the concentrations in these streams, the total load of nitrogen exported from each watershed (fig. 5) has important consequences for downstream receiving waters (see sidebar, Excess Fertilizer in the Environment). The load of nitrogen exported in surface water is the product of the volume of streamflow leaving the watershed and the nitrogen concentration in that water. Both nitrogen concentrations and streamflow, as well as how each varies with time, determine the total annual load of nitrogen exported from each catchment.

- Nitrogen concentrations at the outlet of the California watershed were moderate relative to the other study areas, largely because streamflow generally occurs only during the winter and early spring, when no fertilizer is applied. In addition to the limited time frame during which most runoff occurs, the total volume of surface runoff is small because of the limited precipitation, the use of relatively efficient irrigation methods, and the disconnection between the stream and the deep water table. Moderate concentrations and small flows constrain the load of nitrogen leaving the watershed in surface water. At this site, excess nitrogen leaches into the unsaturated zone, and the small fraction of nitrogen that eventually reaches the deep groundwater is either transformed or eventually discharges to distant streams.

- Nitrogen concentrations also were moderate at the outlet of the Washington watershed. As described above, groundwater base flow at this site contributes a substantial part of the streamflow throughout the year, and moderate nitrogen concentrations can be attributed to conditions along groundwater flow paths that allow for some removal by denitrification to occur. Rill irrigation, the practice of delivering water by flooding furrows between crop rows, is still common in the area, and the practice results in considerable excess water that has, over the past century, caused a rise in the water table to just below land surface. Although peak discharge in DR2 is low relative to streams in the other study watersheds (fig. 4), groundwater discharging to the stream sustains year-round base flow with moderate concentrations of nitrogen. So, despite the arid climate in the Washington study area, the steady base flow results in higher basin yields of both water and nitrogen than any of the other study watersheds.

- Of the five watersheds studied, nitrogen concentrations were highest at the outlet of the Nebraska watershed. Water in this watershed is transported predominantly by overland flow and very shallow subsurface flow derived from precipitation and irrigation, and much of the flow occurs during periods when nitrogen fertilizer is applied to fields. In contrast to groundwater flows, surface-water and very shallow subsurface transport is relatively rapid and direct, allowing less opportunity for biochemical transformations or mixing of different waters. As a result, nitrogen concentrations are relatively high and vary widely.
- Nitrogen concentrations were relatively high at the outlet of the Indiana watershed, but not as high as those measured at the Nebraska site, probably because higher precipitation at the Indiana site dilutes agricultural runoff. Overall, the relatively high rainfall and the efficient transport of water and its nitrogen load by the subsurface drainage system results in moderately high basin yields of both water and nitrogen.

- Of the five watersheds studied, nitrogen concentrations were lowest at the outlet of the Maryland watershed. At this site, water moves predominantly along groundwater flow paths, similar to the Washington site. However, although there is ample time for removal by denitrification to occur, conditions throughout much of the aquifer are not favorable and only limited denitrification occurs. This limited denitrification, coupled with dilution from infiltration of abundant precipitation, acts to lower nitrogen concentrations in groundwater. Steady groundwater discharge to Morgan Creek results in moderately high basin yields of both water and nitrogen.

\section{Implications For Management}

Effective management of agricultural chemicals requires the application of chemicals at the appropriate time and at the appropriate rate, and knowledge of how these chemicals are most likely to be transformed and(or) transported in the range of environmental settings that comprise the Nation's agricultural lands.

Knowledge about the predominant water flow paths (figs. 2 and 3) and understanding their characteristic transport time scales can guide selection of the most effective management practices for particular environmental settings (see sidebar, How Agricultural Fields are Linked to Groundwater and Streams). For example, buffer zones around streams can be effective where overland flow is important, but would be of little value where most water in a watershed travels to the stream through subsurface drains or by deep groundwater flow paths. Knowledge about which water flow paths predominate in particular settings also helps managers develop appropriate monitoring plans. In situations where most water in a watershed is transported along deep groundwater flow paths, responses to management changes may not be apparent in stream-water quality for several years. In contrast, responses in stream chemistry may be apparent almost immediately in areas with short flow paths, such as watersheds with extensive overland flow and/or tile-drain systems.

\section{Ongoing Work}

The USGS is currently studying two additional agricultural watersheds using the same whole-watershed approach (fig. 1). Results from the South Fork Iowa River watershed will add to our understanding of the movement and fate of herbicides and nutrients in Midwestern watersheds dominated by corn and soybean row cropping with extensive surface and subsurface drainage networks. The Bogue Phalia watershed in northwestern Mississippi is dominated by cotton, rice, and soybean row cropping, and the results of work there will increase our knowledge of the movement and fate of pesticides in humid, subtropical agricultural settings. 


\section{References Cited}

Bayless, E.R., Capel, P.D., Barbash, J.E., Webb, R.M.T., Hancock, T.L.C., and Lampe, D.C., 2008, Simulated fate and transport of metolachlor in the unsaturated zone, Maryland, USA: Journal of Environmental Quality, v. 37, p. 1064-1072.

Capel, P.D., Hamilton, P.A., and Erwin, M.L., 2004, Studies by the U.S. Geological Survey on sources, transport, and fate of agricultural chemicals: U.S. Geological Survey Fact Sheet 2004-3098, 4 p., available at http://pubs.usgs.gov/fs/2004/3098/.

Capel, P.D., McCarthy, K.A., and Barbash, J.E., 2008, National, holistic, watershed-scale approach to understand the sources, transport, and fate of agricultural chemicals: Journal of Environmental Quality, v. 37, p. 983-993.

Dodds, W.K., Bouska, W.W., Eitzmann, J.L., Pilger, T.J., Pitts, K.L., Riley, A.J., Schloesser, J.T., and Thornbrugh, D.J., 2009, Eutrophication of U.S. freshwaters-Analysis of potential economic damages: Environmental Science and Technology, v. 43, no. 1, p. 12-19.

Domagalski, J.L., Ator, S., Coupe, R., McCarthy, K., Lampe, D., Sandstrom, M., and Baker, N., 2008, Comparative study of transport processes of nitrogen, phosphorus, and herbicides to streams in five agricultural basins, USA: Journal of Environmental Quality, v. 37, p. 1158-1169.

Essaid, H.I., Zamora, C.M., McCarthy, K.A., Vogel, J.R., and Wilson, J.T., 2008, Using heat to characterize streambed water flux variability in four stream reaches: Journal of Environmental Quality, v. 37, p. 1010-1023.

Fisher, L.H., and Healy, R.W., 2008, Water movement within the unsaturated zone in four agricultural areas of the United States: Journal of Environmental Quality, v. 37, p. 1051-1063.

Green, C.T., Fisher, L.H., and Bekins, B.A., 2008a, Nitrogen fluxes through unsaturated zones in five agricultural settings across the United States: Journal of Environmental Quality, v. 37, p. 1073-1085.
Green, C.T., Puckett, L.J., Böhlke, J.K., Bekins, B.A., Phillips, S.P., Kauffman, L.J., Denver, J.M., and Johnson, H.M. 2008b, Limited occurrence of denitrification in four shallow aquifers in agricultural areas of the United States: Journal of Environmental Quality, v. 37, p. 994-1009.

Hancock, T.C., Sandstrom, M.W., Vogel, J.R., Webb, R.M.T., Bayless, E.R. and Barbash, J.E., 2008, Pesticide fate and transport throughout unsaturated zones in five agricultural settings, USA: Journal of Environmental Quality, v. 37, p. 1086-1100.

Puckett, L.J., Zamora, C., Essaid, H., Wilson, J.T., Johnson, H.M., Brayton, M.J., and Vogel, J.R., 2008, Transport and fate of nitrate at the ground-water/surface-water interface: Journal of Environmental Quality, v. 37, p. 1034-1050.

Steele, G.V., Johnson, H.M., Sandstrom, M.W., Capel, P.D., and Barbash, J.E., 2008, Occurrence and fate of pesticides in four contrasting agricultural settings in the United States: Journal of Environmental Quality, v. 37, p. 1116-1132.

U.S. Environmental Protection Agency, 2008, Mississippi River Gulf of Mexico Watershed Nutrient Task Force: U.S. Environmental Protection Agency Office of Wetlands, Oceans, and Watersheds website, accessed March 24, 2009, at http:// www.epa.gov/msbasin/.

Vogel, J.R., Majewski, M.S., and Capel, P.D., 2008, Pesticides in rain in four agricultural watersheds in the United States: Journal of Environmental Quality, v. 37, p. 1101-1115.

Webb, R.M.T., Wieczorek, M.E., Nolan, B.T., Hancock, T.C., Sandstrom, M.W., Barbash, J.E., Bayless, E.R., Healy, R.W., and Linard, J., 2008, Variations in pesticide leaching related to land use, pesticide properties, and unsaturated zone thickness: Journal of Environmental Quality, v. 37, p. 1145-1157.

USGS promotes public access to water-quality information.

This fact sheet and other publications from the National Water-Quality Assessment Program are available on the World Wide Web at http://water.usgs.gov/nawqa/bib/.

\section{Contacts for additional information:}

Kathleen McCarthy, U.S. Geological Survey (503) 251-3257, mccarthy@usgs.gov

Paul Capel, U.S. Geological Survey

(612)625-3082, capel@usgs.gov 